\title{
sciendo
}

\section{NEW DISTRIBUTION DATA FOR PRUSSIAN CARP Carassius gibelio (BLOCH 1782) IN THE MIDDLE BLACK SEA REGION OF TURKEY}

\author{
Serdar Yedier $^{1 *}$, Derya Bostanci ${ }^{1}$, Nazmi Polat ${ }^{2}$ \\ ${ }^{1}$ Ordu University, Faculty of Arts and Sciences, Ordu-Turkey \\ ${ }^{2}$ Ondokuz Mayıs University, Faculty of Arts and Sciences, Samsun-Turkey \\ *Corresponding Author: serdar7er@gmail.com
}

\section{ARTICLE INFO}

Received: 4 January 2021

Accepted: 18 February 2021

\section{Keywords:}

Invasive fish

Carassius gibelio

Distribution data

Middle Black Sea

\section{ABSTRACT}

In this study, the new occurrence of Carassius gibelio belonging to the genus Carassius in Ulugöl Plateau Pond (Mesudiye-Ordu, Turkey) and Perşembe Plateau Pond (Aybasti-Ordu, Turkey) in the Middle Black Sea Region (Turkey) is reported. The distribution data of Prussian carp was updated in the Middle Black Sea Region of Turkey in comparison to the previously known data. Presenting morphological data of samples collected from two different areas in the Middle Black Sea Region may contribute to revealing the current distribution status of this invasive species and determining the potential distribution areas.

Yedier, S., Bostanci, D., Polat, N. (2021): New distribution data for prussian carp Carassius gibelio (BLOCH 1782) in the Middle Black Sea region of Turkey. Croatian Journal of Fisheries, 79, 83-88. DOI: 10.2478/cjf-20210010. 


\section{INTRODUCTION}

Non-indigenous species are a major global threat to biodiversity with many profound ecological and economic effects (Mack et al., 2000; Lodge, 2001). Additionally, the species are a leading factor in freshwater fish extinctions and endangerments (USFWS, 2012). Discrimination of the invasive fish populations is an important component for the management of invasive species because invader species have ecological impacts on the native communities. For ecologists and population biologists, determination and comparisons of diagnostic characteristics of invasive species and their populations offer unique opportunities to eventually understand the life strategies they use in different ecosystems (Kolar and Lodge, 2002). Population biologists can use the information for controlling the spread and minimizing the damage from invasive species in different habitats (Sakai et al., 2001).

The genus Carassius, a member of the Cyprinidae family, is known for its invasive characteristics and includes six species such as C. auratus (Linnaeus 1758), C. carassius (Linnaeus 1758), C. cuvieri (Temminck \& Schlegel 1846), C. gibelio (Bloch 1782), C. langsdorfii (Temminck \& Schlegel 1846) and C. praecipuus (Kottelat 2017). The expansion of C. gibelio has been realized since the 1600 s, with activities of anglers and the escape from aquaculture farms through river and canal systems (Grabowska et al., 2010).
Although the natural distribution areas of $C$. gibelio are in Korea, northeastern China and Russia (Kottelat and Freyhof, 2007), they have dominated the inland waters of many countries thanks to their high reproductive capacity and unique adaptability (Tarkan et al., 2012a). The existence of $C$. gibelio in Turkish inland waters was first reported in Lake Gala in 1986 (Baran and Ongan, 1988). The rapid spread of invasive species in Turkish inland waters was reported in many studies which led to a negative impact on native species and local habitats (İnnal and Erk'akan, 2006; Tarkan et al., 2012b; Illhan et al., 2020). In a few studies, C. gibelio was previously reported in the Middle Black Sea Region (Yılmaz et al., 2012; Bostanci et al., 2016; Macun, 2018; Akbay, 2019). In the current study, the expansion of the distribution of C. gibelio was reported in the inland waters of the Ordu province in the Middle Black Sea Region.

\section{MATERIAL AND METHODS}

The sampling sites were Ulugöl Plateau Pond $\left(40^{\circ} 23^{\prime} 56.5^{\prime \prime} \mathrm{N}\right.$ - 37 50'00.7"E) (Mesudiye-Ordu, Turkey) and Perşembe Plateau Pond $\left(40^{\circ} 37^{\prime} 33.2^{\prime \prime} \mathrm{N}\right.$ - 37¹7'42.7"E) (AybastOrdu, Turkey) in the Middle Black Sea Region (Turkey). The sampling areas are given in Figure 1.
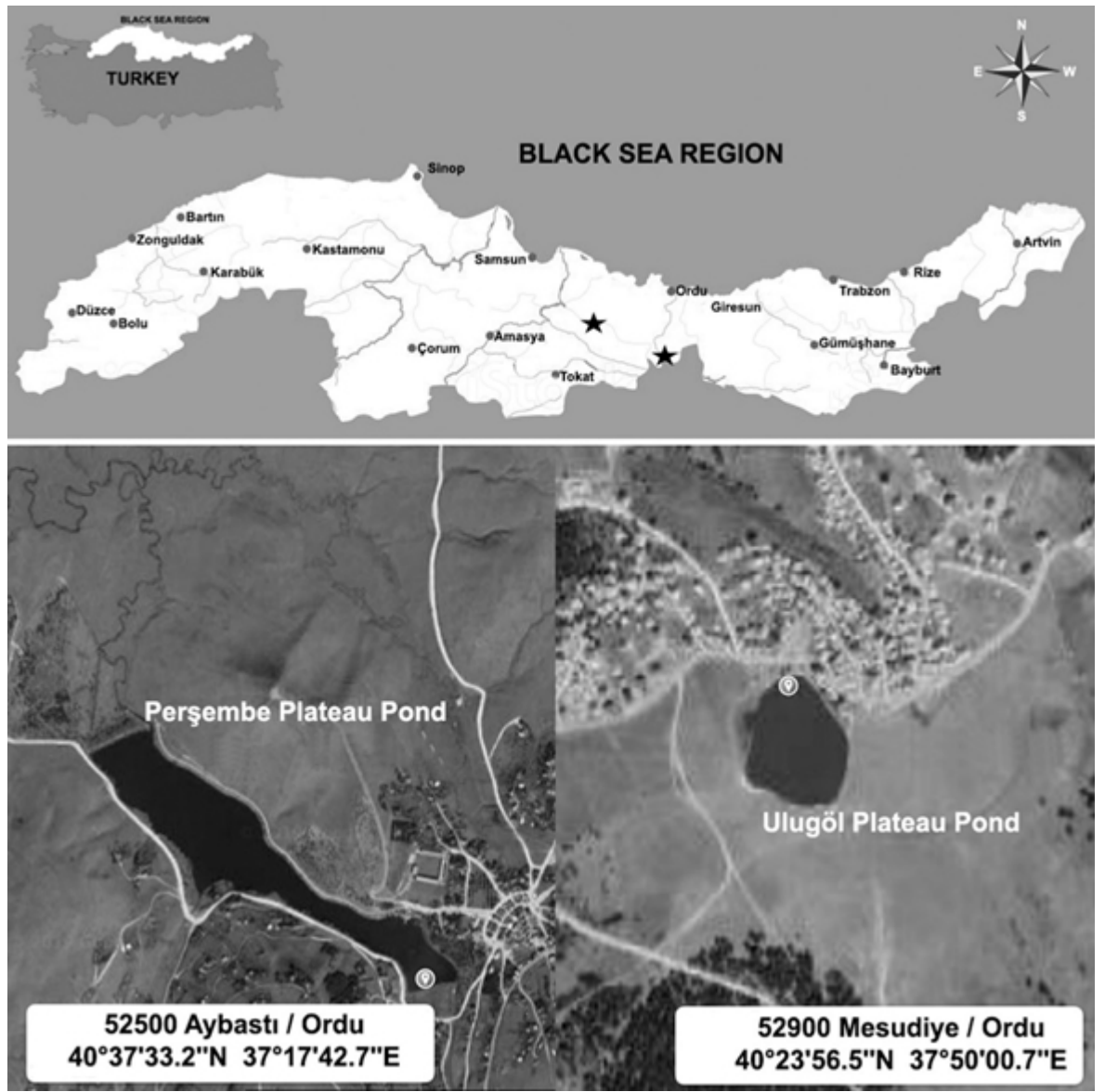

Fig 1. Sampling locations of Carassius gibelio in the Middle Black Sea Region of Turkey 
Necessary permissions were obtained from the Republic of Turkey, Ministry of Agriculture and Forestry, General Directorate of Fisheries and Fisheries for fishing in the protected areas (No:67852565-140.03.03-E.3511538). The fish samples were captured along the shallow shores of Perşembe Plateau Pond and Ulugöl Plateau Pond using the electro shocker. Standard (SL), fork (FL) and total lengths (TL) of the samples were measured (nearest 0.1 $\mathrm{cm}$ ) and their body weight (nearest $0.01 \mathrm{~g}$ ) was recorded. Besides, some meristic characters of the samples were also determined. In the present study, fish samples were sexed by visual examination of the gonads.

\section{RESULTS}

In the current study, C. gibelio samples were collected in Ulugöl Plateau Pond (Mesudiye-Ordu, Turkey) (altitude: 1614 m; perimeter: $450 \mathrm{~m}$; surface area: $14100 \mathrm{~m}^{2}$ ) and Perşembe Plateau Pond (Aybast-Ordu, Turkey) (altitude: 1440 m; perimeter: 2644 m; surface area: $139200 \mathrm{~m}^{2}$ ) in the Middle Black Sea Region (Turkey).

A total of 24 individuals were captured from Ulugöl Plateau Pond and Perşembe Plateau Pond in the present study. Samples were sexed as 10 male and 14 female samples. The total length, fork length, standard length and body weights of all samples varied as $6.9-22.5 \mathrm{~cm}(12.8 \pm 0.7)$, 6.0-20.0 cm (11.5 \pm 0.7$), 5.4-17.9 \mathrm{~cm}(10.0 \pm 0.6)$ and 3.6$159.8 \mathrm{~g}(40.5 \pm 7.3)$, respectively. Meristic characters of the C. gibelio samples were counted as D: III-IV, 14-15; A: III, $5, \mathrm{~V}:$ II, 7-8; P: I, 15-17. The number of scales on the lateral line is 29-32, and the free edge of the dorsal fin is concave or straight. Male and female specimens of $C$. gibelio were presented in Figure 2. The back of this species is blackishgray and the peritoneum is black.

\section{DISCUSSION}

Ichthyofauna research is important for the detection of biodiversity, conservation and sustainability of gene resources. Turkey's inland water fish fauna is undergoing constant change due to many different factors such as environmental pollution, the release of predator fish into the water, untimely and overfishing with irregular methods (Bostanci et al., 2016).

C. gibelio was previously reported in Lake Gaga and the Curi Stream (Ordu, Turkey) (Yerli et al., 2014; Bostanci et al., 2016; Dönel and Yılmaz, 2016). In the current study, the presences of $C$. gibelio in two new habitats in the inland waters of Ordu are determined. These two habitats are Perşembe Plateau Pond and Ulugöl Plateau Pond. There is no previous record of the distribution of this species in these habitats. $C$. gibelio rapidly increases the number in Turkish inland waters; it is not clear how the species enters Turkish inland waters, but it is estimated that it is due to the stocking activities by individuals and public institutions (Bostanci et al., 2016). The presence of Cyprinus carpio in Perşembe Plateau Pond and Ulugöl Plateau Pond are also determined; therefore, it is estimated that $C$. gibelio was accidentally released during the stocking activities of carp in these habitats.

Stocking projects were carried out by public institutions which aim to increase the sportfishing and the diversity of economic fish species in rivers, lakes and ponds, and to repair the ecosystem (Tarkan et al., 2012b). However, the biggest deficiency in this regard is the lack of scientific research, prior to the project, on whether domestic species and other species planned to be stocked in the habitat would live in harmony in this habitat. When the previous distribution of $C$. gibelio was reviewed in the

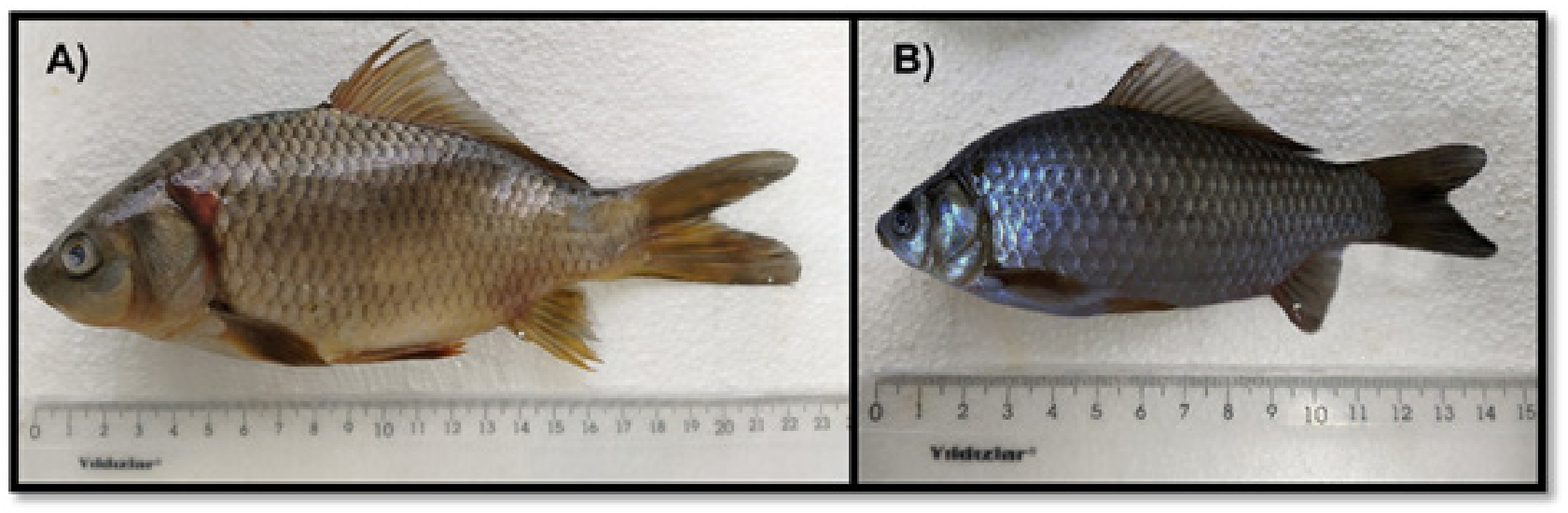

Fig 2. Female and male Carassius gibelio samples were collected from the Middle Black Sea Region, (A) female, $22.5 \mathrm{~cm}$ $\mathrm{TL}$; B) male, $14.4 \mathrm{~cm} \mathrm{TL)}$ 
literature, it is thought that both interconnected aquatic systems and the human factor are effective in expanding the distribution area of these fish species (Tarkan, 2013). The Black Sea Region has eighteen cities such as Amasya, Artvin, Bartn, Bayburt, Bolu, Çorum, Düzce, Giresun, Gümüşhane, Karabuk, Kastamonu, Ordu, Rize, Samsun, Sinop, Tokat, Trabzon and Zonguldak. There are five provinces such as Samsun, Amasya, Tokat, Ordu and Çorum in the Middle Black Sea Region. The first records of the distribution of $C$. gibelio in Suat Uğurlu Dam Lake in the Middle Black Sea Region were determined in 2005 (Uğurlu and Polat, 2005) but it had spread to a large part of the region. In this region, the presence of 22 different habitats of this species was reported from 2005 until 2016 (Table 1). In the present study, two new habitats (Perşembe Plateau Pond and Ulugöl Plateau Pond) were added to these data.

Increasing the amount of aquaculture obtained from Turkish freshwater sources and determining other biological riches, especially fish fauna, can be realized as a result of fully and accurately revealing the biodiversity. In order to prevent losses in biodiversity, conservation studies should be carried out both on a habitat and species basis. At the beginning of these studies, the determination of the existing diversity and the determination of the factors causing problems are the most important ones. Detection of invasive species that have a destructive effect on our existing indigenous species in inland waters, and action plans to be prepared against them, is very important. Necessary measures should be taken to prevent this fish from spreading from these habitats to other inland waters of Ordu and to prevent possible threats to other native species in these habitats. For instance, in order to prevent the spread of $C$. gibelio, local people should be made aware of invasive fish. In addition, it should be explained that local fishermen should not use the same fishing gear in every habitat in order to prevent the eggs and larvae of this species from being transported to other ecosystems.

Table 1. Distribution areas of C. gibelio in the Middle Black Sea Region of Turkey

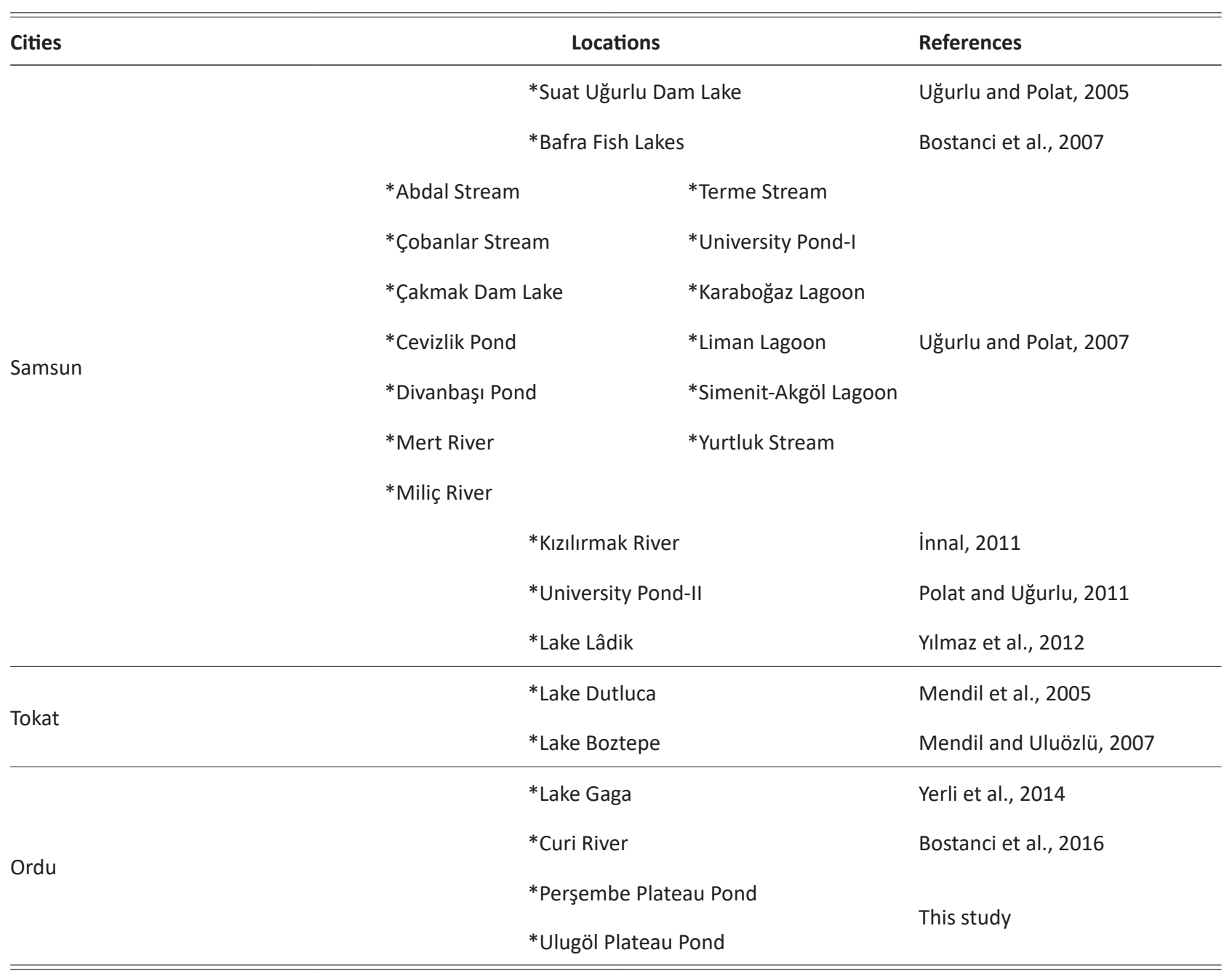




\section{NOVI PODACI O DISTRIBUCIJI BABUŠKE Caras- sius gibelio (BLOCH 1782.) U REGIJI SREDNJEG CRNOG MORA U TURSKOJ}

\section{SAŽETAK}

U ovom radu prikazana je nova pojava babuške $C$. gibelio koja pripada rodu Carassius u jezerima Ulugöl Plateau (Mesudiye-Ordu, Turska) Perşembe Plateau (AybastOrdu, Turska) u regiji srednjeg Crnog mora (Turska). Podaci o distribuciji babuške ažurirani su u usporedbi s ranije poznatim podacima u srednjem crnomorskom području Turske. Prikaz rezultata nekih morfoloških podataka uzoraka, prikupljenih s dva različita područja u regiji srednjeg Crnog mora, može doprinijeti utvrđivanju trenutnog statusa rasprostranjenosti ove invazivne vrste i određivanju potencijalnih područja rasprostranjenosti.

Ključne riječi: invazivna riba, Carassius gibelio, podaci o distribuciji, srednje Crno more

\section{REFERENCES}

Akbay, R. (2019): Lagenar otolith morphology and morphometry of an invasive species, Carassius gibelio (Bloch, 1782): Comparisons among four populations in Samsun (Turkey). Ondokuz Mayıs University, Samsun, Turkey. 98 p.

Baran, i, Ongan, T. (1988): Gala Gölü'nün limnolojik özellikleri, balıkçılık sorunları ve öneriler. Gala Gölü ve Sorunları Sempozyumu; Doğal Hayatı Koruma Derneği Bilimsel Yayınlar Serisi, İstanbul, Turkey. p. 46-54. (in Turkish)

Bostanci, D., İskender, R., Helli, S., Polat, N. (2016): The fish of the Curi Stream (Ordu) and invasive fish species Carassius gibelio (Bloch, 1782). Journal of Aquaculture Engineering and Fisheries Research, 2, 1, 11-19. (Article in Turkish, Abstract in English)

Bostanci, D., Polat, N., Kandemir, Ş., Yılmaz, S. (2007): Determination of condition factor and length-weight relationship of the crucian carp, Carassius gibelio (Bloch, 1782) inhabiting Bafra Fish Lake. SDÜ Fen Edebiyat Fakültesi Fen Dergisi, 2, 2, 117-125. (Article in Turkish, Abstract in English)

Dönel, E.K., Yılmaz, E. (2016): The fish fauna of Gaga Lake (Ordu-Turkey) and identification of four species by morphometric characteristics. Turkish Journal of Maritime and Marine Sciences, 2, 63-74. (Article in Turkish, Abstract in English)

Grabowska, J., Kotusz, J., Witkowski, A. (2010): Alien invasive species in Polish waters: an overview. Folia Zoologica, 59, 1, 73-85.

IIlhan, A., Sarı, H.M., Kurtul, I. (2020): Growth parameters of invasive gibel carp Carassius gibelio (Bloch, 1782) in Lake Marmara (Turkey). Oceanological and Hydrobiological Studies, 49, 383-390.
Innal, D. (2011): Distribution and impacts of Carassius species (Cyprinidae) in Turkey: a review. Management of Biological Invasions, 2, 57-68.

Innal, D., Erk'akan, F. (2006): Effects of exotic and translocated fish species in the inland waters of Turkey. Reviews in Fish Biology and Fisheries, 16, 39-50.

Kolar, C.S., Lodge, D.M. (2002): Ecological predictions and risk assessment for alien fishes in North America. Science, 298, 1233-1236.

Kottelat, M., Freyhof, J. (2007): Handbook of European Freshwater Fishes. Kottelat and Freyhof, Cornol and Berlin, 646pp.

Lodge, D.M. (2001): Responses of lake biodiversity to global changes. In: F.S. Chapin, O.E. Sala and E. HuberSannwald, eds) Future scenarios of global biodiversity. Springer-Verlag, New York. pp. 277-312.

Mack, R.N., Simberloff, D., Lonsdale, W.M., Evans, H., Clout, M., Bazzaz, F.A. (2000): Biotic invasions: causes, epidemiology, global consequences, and control. Ecological Applications, 10, 689-710.

Macun, S. (2018): Determination of some fish species trophic level in the Bafra Balık Lakes (Lake Balık and Uzungöl). Hacettepe University, Ankara, Turkey. 188 p.

Mendil, D., Uluözlü, Ö.D. (2007): Determination of trace metal levels in sediment and five fish species from lakes in Tokat, Turkey. Food Chemistry, 101, 739-745.

Mendil, D., Uluözlü, Ö.D., Hasdemir, E., Tüzen, M., Sari, H., Suiçmez, M. (2005): Determination of trace metal levels in seven fish species in lakes in Tokat, Turkey. Food Chemistry, 90, 175-179.

Polat, N., Uğurlu, S. (2011). Samsun ili tatlı su balık faunası. Ceylan Ofset, Samsun, Turkey. 272pp. (in Turkish)

Sakai, A.K., Allendorf, F.W., Holt, J.S., Lodge, D.M., Molofsky, J., With, K.A., Baughman, S., Cabin, R.J., Cohen, J.E., Ellstrand, N.C., McCauley, D.E., O'Neil, P., Parker, I.M., Thompson, J.N., Weller, S.G. (2001): The population biology of invasive species. Annual Review of Ecology and Systematics, 32, 305-332.

Tarkan, A.S. (2013): Introduction pathways, impacts and protection measures of non-native freshwater fishes in Turkey and the World. Journal of Fisheries \& Aquatic Sciences, 28, 1, 63-104.

Tarkan, A.S., Copp, G.H., Top, N., Özdemir, N., Önsoy, B., Bilge, G., Filiz, H., Yapıcı, S., Ekmekçi, G., Kırankaya, Ş., Emiroğlu, Ö., Gaygusuz, Ö., Gürsoy Gaygusuz, Ç., Oymak, A., Özcan, G., Saç, G. (2012b): Are introduced gibel carp Carassius gibelio in Turkey more invasive in artificial than in natural waters? Fisheries Management and Ecology, 19, 178-187.

Tarkan, A.S., Gaygusuz, Ö., Gürsoy Gaygusuz, Ç., Saç, G., Copp, G.H. (2012a): Circumstantial evidence of gibel carp Carassius gibelio reproductive competition exerted on native fish species in a mesotrophic reservoir. Fisheries Management and Ecology, 19, 167177.

Uğurlu, S., Polat, N. (2005): The fishes inhabiting in Suat Uğurlu Dam Lake, Terice and Göksu Stream (Ayvacık- 
Samsun). Süleyman Demirel University Journal of Eğirdir Fisheries Faculty, 1, 2, 27-37. (Article in Turkish, Abstract in English)

Uğurlu, S., Polat, N. (2007): Exotic fish species inhabiting in freshwater sources within the province of Samsun. Journal of FisheriesSciences.com, 1, 3, 139-151. (Article in Turkish, Abstract in English)

USFWS (U.S. Fish and Wildlife Service) (2012): The cost of invasive species. [cited 2019 June 26]. Available from: http://www.fws.gov/verobeach/PythonPDF/ CostofInvasivesFactSheet.pdf.
Yerli, S.V., Mangıt, F., Emiroğlu, Ö., Yeğen, V., Uysal, R., Ünlü, E., Alp, A., Buhan, E., Yıldırım, T., Zengin, M. (2014): Distribution of invasive Carassius gibelio (Bloch, 1782) (Teleostei: Cyprinidae) in Turkey. Turkish Journal of Fisheries and Aquatic Sciences, 14, 2, 581-590.

Yılmaz, S., Yazıcıoğlu, O, Erbaşaran, M., Esen, S., Zengin, M., Polat, N. (2012): Length-weight relationship and relative condition factor of white bream, Blicca bjoerkna (L., 1758), from Lake Ladik, Turkey. Journal of the Black Sea/Mediterranean Environment, 18, 3, 380387. 